STEVE ELLMERS is winner of the 2019 Unitec Dean's Award for Research.

\section{Māori and Pākehā newspapers vied for audience in colonial New Zealand}

Lasting Impressions: The story of New Zealand's newspapers, 1840-1920, by lan F. Grant. Masterton, New Zealand: Fraser Books, 2018. 676 pages. ISBN 978-0-9941360-4-6

AN F. GRANT'S Lasting Impressions is a magisterial history of New Zealand's early newspapers and is the culmination of many years of research as well as a life-long fascination with this country's print media. The Alexander Turnbull Library's first adjunct scholar has produced more than just the definitive account of how this industry rose and developed between 1840 and 1920; he has also written an enthralling tale of the making of New Zealand.

Grant is not afraid to challenge the stereotypes and assumptions that have clouded the previous scholarship on this era either. His unparalleled archival access and analysis combined with his instincts as an industry insider have allowed him to place what occurred between the birth and subsequent early adulthood of New Zealand's media within their actual context. The geo-

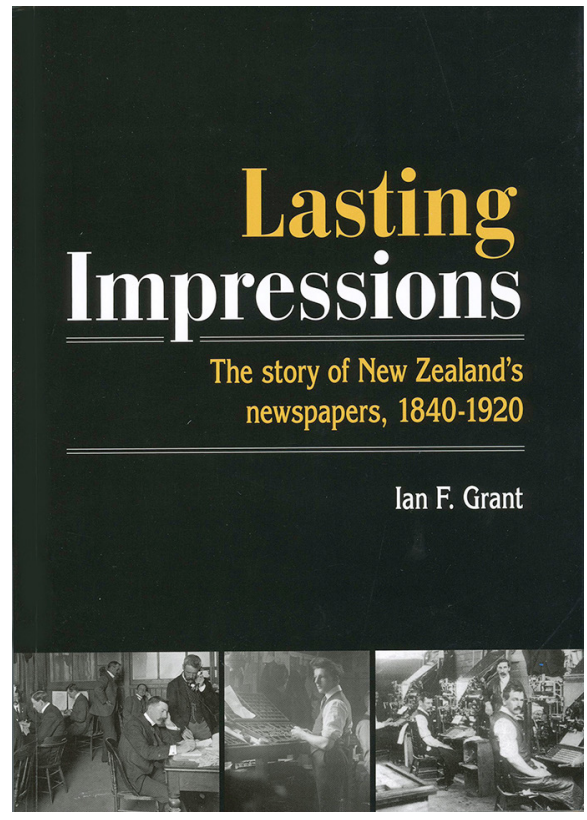

graphical and social isolation of the European settlers shaped the newspapers that arose to serve their needs.

Grant does not dispute that a few of these publications were also used as vehicles for the political aspirations of their proprietors. However, he conclusively shows that the outlets concerned succeeded despite, rather than because of, these factors.

The scarcity of essential goods in the new colonies ensured that news of their arrival always took precedence over everything else. In the pretelegraph age even news from Britain took months to reach our shores. As a result, announcing which merchants had received new shipments meant that advertising comprised the majority of the first newspapers' content.

Even then this was not enough to guarantee their financial viability. Stationary sales and printing to order 
were also essential to these early businesses while the small readership with the leisure and inclination to follow international affairs would have to be content with whatever could be reproduced verbatim from the papers the ships carried out from England.

In this environment newspapers were ventures which their ownerslike many new migrants-were forced to embark on.

The beginning of mass literacy and the dearth of economic alternatives meant that some entrepreneurs saw them as one of the few ways they could secure a toehold in a distant land and, potentially, their commercial futures. As their success or failure were invariably intertwined with those of the communities they reported on there was an understandable surge of cheerleading.

Yet any personal political stance they adopted could alienate the very readers and advertisers upon whom they were dependant if it didn't represent the general feeling in their individual settlements.

Māori newspapers are also given their rightful place as the voice of the most literate of all indigenous peoples. Grant draws a strong distinction between the Māori-owned publications and those produced in te reo Māori by Pākehā governments, churches, and philanthropists.

During a period dominated by land disputes and conflict between Māori and Pākehā, the papers concerned were engaged in an information war that relied on prose that drew upon the poetic oral traditions of their reader- ship. However, there is no disguising the existential stakes involved when the very language they were printed in was at risk of disappearing.

By the outbreak of World War One in 1914 Lasting Impressions has traversed the most transformative era in New Zealand's history. The familiar Dominion has begun to take shape and the newspaper environment we have come to expect, regardless of its flamboyant failures and remarkable successes, has emerged.

This journey from what the transTasman World initially referred to as Māoriland (it was an especially favoured term of Australia's leading colonial journal, The Bulletin) to something utterly unrecognisable a few decades later, is truly a delight to read. Grant has avoided a 'dry as dust' treatment and concentrated on bringing to life the details and impact of a profound communications and social revolution.

His achievement will tower over everything that comes after it well into the second half of this century and it can only be hoped that the author completes his anthology up to the present day - and causes every New Zealand academic and public library to set aside additional shelf space for the companion volume.

Nor do you have to bleed ink in order to add it to your personal collection. If you profess to be a scholar of New Zealand media or even a slightly interested amateur, then owning it is a must. 